\title{
Hot-Spot Biodiversity Approach by using Birds as Indicators for Development of Ecotourism
}

\author{
Yan E. Persulessy ${ }^{1}$, Robert Oszaer $^{2}$ and Jusmy D. Putuhena ${ }^{2^{*}}$ \\ ${ }^{1}$ Postgraduate Student of Forest Management of Pattimura University, Indonesia \\ ${ }^{2}$ Department of Forestry Pattimura University, Indonesia \\ *Corresponding author
}

\section{Keywords \\ PFMU, Hot-spot biodiversity, Birds, ecotourism, Bird Watching \\ Article Info \\ Accepted: \\ 15 January 2019 \\ Available Online: \\ 10 February 2019}

\section{A B S T R A C T}

Hot-spot biodiversity is a concentrated site of high species diversity, high species endemicity, and habitat uniqueness. Biodiversity disperses unevenly across the global, regional and regional scope. Hot-spot biodiversity developed into an approach to assessing the concentration of biodiversity at certain limits. The biodiversity hot-spot approach is conducted using indicator species such as bird species that are used as ecotourism development for sustainable forest exploitation. Research with objectives: Determine the location of biodiversity hot-spot within Production Forest Management Unit (PFMU) Wae Sapalewa area, measure the importance of hot spot location, and provide appropriate ecotourism form directions at hot spot locations. The research used survey method with area tracing technique to determine the biodiversity hotspots as well as Point Count and Encounter Rates method to collect information of indicator bird species. The results of the study determined 7 locations of biodiversity hot-spot within PFMU Wae Sapalewa area which contained tourist attraction object, in the form of bird species biodiversity with certain status. It is recorded as many as 122 species of birds; 4 endangered species globally, 9 species endemic Seram Island, 6 unique species, 21 types of limited distribution. This particular type of bird is classified into 27 species of "Bird Indicators" considered as objects of ecotourism attraction. Calculation Index of diversity type shows 7 hot-spot location has high diversity index value, calculation result of relative abundance of indicator bird species shows variation of abundance which is indicative of existence condition and status of bird species in hot spot location. The results of the analysis lead to the form of ecotourism in the form of ecotourism of special interest in the form of Bird Watching.

\section{Introduction}

\section{Background}

An important aspect of ecotourism development in a location is the existence of objects that have unique values and specific characteristics such as biodiversity. The existence of biodiversity does not spread evenly but is concentrated in a particular location. The locations that are concentrated in biodiversity are known as "hot-spot biodiversity" (Virk, 1988 in Indrawan et al., 2007). 
Hot-spot biodiversity can be an ecotourism management area and if you see the characteristics of biodiversity hot spots can be used as a priority governance area (Sujatnika et al., 1995). Hot-spot biodiversity can also be classified as a strategic area. Law No.10 Year 1990 on Tourism states that the determination of strategic areas is done with attention to natural tourism resources and cultural potential. The area should be an important consideration in tourism execution. Hot-spot biodiversity will help ecotourism management in a location because most of the resources owned by the management organization will be directed to the hot spot location, so management will run maximally and effectively (Sujatnika et al., 1995).

Location of hot-spot biodiversity is generally located within the forest area. Ridwan (2000) states that ecotourism can be developed in production forest areas and protected forests that have a specialty or uniqueness. Currently forestry development is directed to forest management in accordance with its main function and allocation, for which the government has issued a policy on development of Forest Management Unit based on Forestry Ministerial Decree No.230 / Kpts-II / 2003. Forest Management Unit (FMU) that has been established in Maluku Province as many as 22, one of them is PFMU Wai Sapalewa which is determined through Minister of Forestry Decree No. 336 / Ministry of Forestry-II / 2010 dated 25 May 2010, covering 67,057 ha located in North Seram Sub District, Central Maluku Regency.

One of the targets of FMU development is the utilization of environmental services that can be managed according to their designated areas at the site level. Utilization of environmental services can be done by developing ecotourism that aims to protect and preserve the environment (Lindberg, 1991). The development of ecotourism in forest areas in some countries has provided great benefits to the community (Fandeli, 2000). Ecotourism also supports natural resource conservation indicators (Agrawal and Redford, 2006). In addition, ecotourism also contributes greatly to the national income of a country (Wallace, 1993). Based on the benefits of ecotourism development, it is possible to develop ecotourism within the FMU area.

Ecotourism development is based on the potential of a forest area. Biodiversity is a potential that can be the object of tourist attraction. But it takes a picture of the concentration of biodiversity. For that purpose, this study will be conducted by determining the location of hot-spot biodiversity by using bird species as an indicator to provide an overview of biodiversity concentration within PFMU Wae Sapalewa area. Birds are used because they have been proven in many places as good indicators for assessing community diversity (Ricketts et al., 1999 in Indrawan et al., 2007).

\section{The problem formulation}

PFMU Wae Sapalewa is an FMU intended for timber forest production, where timber from tree becomes the core business for FMU. However, there are management blocks that are intended for other activities in the context of sustainable forest management, such as limited-scale nature tourism or ecotourism. PFMU Wae Sapalewa does not have the concept of ecotourism development in accordance with its potential, while the potential of ecotourism objects are scattered within its territory, but the data and information are not available properly.

Development of ecotourism by exploiting the potential of biodiversity as a tourist attraction is not easy, this condition requires an 
effective approach method that can provide adequate data and information. Hot-spot biodiversity becomes a strategic approach for this purpose, where biodiversity is studied using birds as an indicator to know the diversity of communities.

Based on the above problem, the research question is how to determine the location of hot-spot biodiversity by using bird as indicator, and what form of ecotourism is most suitable to be applied in hot-spot locations of biodiversity within FMU Wae Sapalewa area.

\section{Purpose}

Determine the location of the habitat sample and study it into a hot-spot location of biodiversity within the PFMU Wae Sapalewa area.

Measure the importance of hot-spot biodiversity locations by measuring the diversity of the indicator bird species.

Provide direction of appropriate ecotourism form at the hot-spot location of biodiversity.

\section{Materials and Methods}

\section{Location and time of study}

The research was conducted in PFMU Wai Sapalewa area, North Seram District, Central Maluku District, Maluku Province. Implementation of research and writing of the results take place between 2015 and 2017.

\section{Data collection}

\section{Terrestrial search and hot-spot location biodiversity determination}

Regional searches are conducted to ensure biodiversity potential. Site search locations were selected based on a review of land cover maps and previous research report information, such as Natural History of Seram (Ian D. Edwards at all, 1993), territorial searches using work-paths, each region traced for 2 to 3 days.

Locations that have high biodiversity records of bird species are designated as habitat samples. The location of this habitat sample is further investigated to be designated as a hotspot biodiversity location. Determining the location of habitat samples as hot-spot biodiversity locations used the following criteria for determining the location of biodiversity hotspots. The criteria are based on Law No.5 / 1990 on Conservation of Biological Natural Resources and Ecosystems; Sujatnika et al., (1995); Law No. 41 Year 1999 on Forestry: Dobson et al., (1997) and Flather et al., (1998) in Indrawan et al., (2007); Forest Area Conservation Center Region IX Ambon (2013);

Have a wealth of high biodiversity, according to region search results.

Includes protected areas such as river borders, springs, unique habitats, and attractive landscapes.

Includes the representation of various types of important land cover formations.

Includes Protected Forest Areas that already exist.

Excluding block of timber forest product processing according to PFMU Wae Sapalewa plan.

Form hot-spot areas wherever possible following the block or sub-block of PFMU management Wae Sapalewa to facilitate the orientation of border areas in the field.

\section{Bird type data collection}

The data collection method refers to Colin Bibby at all (1994) in Sozer et al., (2000);

Point count is a circular area, where the observer stands in the middle while looking in all directions for data collection within 15 
minutes. Point Count is placed in the work path or transect. Each Point Count in a transect is also called a data collection station.

\section{Point point count in the field}

Total length of transect at hotspot location $10.8 \mathrm{Km}$, divided by 4 work path along 2.7 $\mathrm{Km}$.

The length of the Count Circle field is $300 \mathrm{~m}$. long radius of circle $150 \mathrm{~m}$. Point Count is placed in transect with distance between middle field $300 \mathrm{~m}$.

Each transect has 10 Point Count, with 4 transects in each hot spot location, so there are 40 Count at each hot spot location.

Encounter rates is a way of collecting data variables to measure wealth and species diversity. The main data variables collected include; bird species, number of individual types, and hours of observation, as well as other data variables.

\section{Analysis method}

\section{Relative abundance}

Relative abundance is only intended for the analysis of bird species indicator species that are considered attractive as an ecotourism attraction.

\section{Abundance class based on observation hours}

The relative abundance of observation hours is based on the total time of observed bird species, then dividing the total time into several categories of abundance classes. The division of abundance classes was made according to the abundance class of Lowen $e t$ al., (1996) in Sozer et al., (2000) modified as presented below.

\begin{tabular}{|c|c|c|}
\hline $\begin{array}{c}\text { Abundance } \\
\text { category }\end{array}$ & $\begin{array}{c}\text { Abundance } \\
\text { Value }\end{array}$ & $\begin{array}{c}\text { Abundance } \\
\text { Class }\end{array}$ \\
\hline \hline$<20$ minutes & 1 & rare \\
\hline $21-50$ minutes & 2 & Not common \\
\hline $51-100$ minutes & 3 & Often \\
\hline $101-200$ \\
minutes
\end{tabular}

\section{Frequency of availability}

Frequency of availability refers to the number of data collection stations in which a bird species is observed in comparison with the total number of stations used, Frequency of availability using the equations of Misra (1968);

\section{Number of stations of $i$-species observed \\ $\mathbf{F i}=$ Number of all observation stations}

\begin{tabular}{l}
$\begin{array}{l}\text { Category of frequency of } \\
\text { availability; } \\
\text { - Low }(<10 \%) \\
\text { - Medium }(10-50 \%) ;\end{array}$ \\
\hline
\end{tabular}

\section{Diversity Index}

Diversity indices are used for analysis of all bird species encountered.

The wealth index ( $\left.\mathbf{R}_{\mathbf{1}}\right)$, Margalef's equation (1958) in Bratawinata (2001). 


$$
\mathbf{R}=\frac{(\mathbf{S}-\mathbf{1})}{\text { Ln. } \mathbf{N}} \quad \begin{aligned}
& \text { Information: } \\
& \mathrm{R}=\text { Wealth index of Margalef's type } \\
& \mathrm{S}=\text { the number of species observed } \\
& \mathrm{N}=\text { the number of individuals of all } \\
& \text { types } \\
& \text { Ln }=\text { natural logarithm values }
\end{aligned}
$$

Category of wealth index:

$\mathrm{R}<2,5 \quad$ Low type of Wealth

$2,5>\mathrm{R}<4$ Medium type of

Wealth

Diversity Index (H'), the Shanon-Wiener equation (1949) in Bratawinata (2001).

$$
\begin{aligned}
& \text { Keterangan: } \\
& H^{\prime}=-\sum_{i=1}^{n} p i \ln p i \quad \begin{array}{l}
\mathrm{H}^{\prime}=\text { index of diversity } \\
\begin{array}{l}
\mathrm{pi}_{\mathrm{i}}=\mathrm{n}_{\mathrm{i}} / \mathrm{N} \\
\text { of } \mathrm{i}
\end{array} \\
\\
\begin{array}{l}
\mathrm{N}=\text { total number of individual types } \\
\text { tune }
\end{array}
\end{array}
\end{aligned}
$$

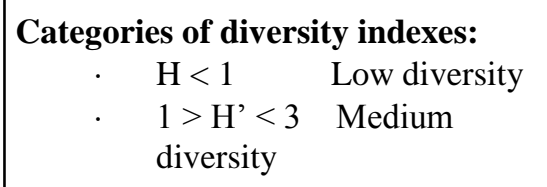

The Equity Index, the Magurran equation (1988) in Soerianegara and Indrawan (2005).

$$
\begin{aligned}
& E=\frac{H^{\prime}}{H_{\text {maks }}} \\
& \begin{array}{l}
\text { Information: } \\
\begin{aligned}
E & =\text { uniformity index } \\
H_{\text {maks }} & =\ln \mathrm{S} \\
\mathrm{S} & =\text { number of species }
\end{aligned}
\end{array}
\end{aligned}
$$

\section{Categories of diversity indexes:}

- E close to 0:

Individual distribution between species is uneven

- E close to 1:

Individual distribution among species is even distributed

\section{Results and Discussion}

\section{Hot-spot biodiversity location}

There are 11 locations selected in the territorial search, the condition of the area being searched is presented in Table 1.

The eleven locations searched have different species of birds. Table 2 shows that; there are 9 locations that have records of the diversity of bird species are high from 51 to 70 types namely; location of Masihulan, Mt. Kaluala, Huaulu, Roho, Mt. Kalapahin, Wai Puti-puti, Solea and Old Solea. While the two locations have a record of the diversity of bird species are low from 43 to 46 types namely; Mt. Pasasana and Rumasokat.

Based on consideration of location access, Solea lama as a location that is too far and isolated is removed, thus there are only 8 locations that are considered appropriate as the location of the sample habitat for further study. The distribution of the territorial search path and the location of the habitat sample are presented in Figure 2.

Based on Hot-spot Location Determination Criteria, referring to Map of PFMU Management Block Division Wae Sapalewa (Forest Area Conservation Center, 2013), which is associated with data of regional search results, the location of Melinani is removed because it is within the non-timber forest products utilization block.

Therefore, there are 7 locations which meets the Hot-spot criteria as the Hot-spot of Biodiversity location within the PFMU Wae Sapalewa area, see Table 3. The position and distribution of 7 Hot-spot Biodiversity locations in the PFMU Wae Sapalewa region is presented in Figure 3. 
Figure 3 shows that there is a hot-spot location whose form and boundary follows completely as a management block; such as hot spot locations located in Protected Forests / Core Blocks, Production Forests / Special Blocks and Production Forests / Blocks of Protection. Then, there is a hot-spot location whose territorial boundary covers only a portion of the management block form, such as in Production Forest / Area utilization Block. Determining the shape and boundaries of hot spot locations in more detail utilizes the sub-block dividing boundaries, also using ridge areas and river borders.

\section{Bird species diversity at hot-spot locations of biodiversity}

Bird species found in 7 hot-spot locations recorded as many as 122 species, consisting of 96 Genus and 47 families.

There are 3 families whose dominant species are; COLUMBIDAE 14 types, then PSITTACIDAE 11 types, and ACCIPITRIDAE 9 types. Based on the status of the species, there are 4 endangered birds according to the IUCN list.

They are 6 unique birds species, 9 species of endemic birds of Seram Island and surrounding islands, and 21 limited bird species.

The bird species with specific status are classified as 27 species of indicator bird; namely the type that is considered interesting as the object of attraction of ecotourism. The overall profile of bird species found in hotspot biodiversity locations is presented in the diagram form in Figure 4.

Bird species encounter in the hot-spot locations in detail is presented in Figure 5
In categories of total species, there are 3 locations of hot spots with the most total number of species, namely Hot-spot Solea as many as 98 species, Hot-spot Masihulan 97 types, and Hot-spot Wai cover 90 types. Then followed by Hot-spot Gn. Kaluala 87 type, Hot-spot Huaulu 85 type and 75 species of Roho Hot-spot.

Hot-spot Gn Kalapahin is a hot-spot location with the lowest total species of 65 species.

In the category of bird indicator, Hot-spot Masihulan and Gn. Kaluala has the most number of bird indicator species, as many as 25 species.

On Hot-spot Roho and Solea found 22 types, on the Hot-spot Gn. Kalapahin found 21 types, Hot-spot Huaulu found 20 species, and Hot-spot Wai Putiputi only found 19 species.

In the category of endemic bird species, the Hot-spot Masihulan and Gn. Kaluala encountered 8 types, then Hot-spot Roho; Gn. Kalapahin; and Wai Putiputi found 7 types, then Hot-spot Solea found 6 types, and in Hot-spot Huaulu only found 5 types.

In the category of bird species that are unique, the Hot-spot Masihulan and Gn. Kaluala found 6 types, on Hot-spot Solea there are 5 types, then on Hot-spot Huaulu, Roho, Gn. Kalapahin and Wai Putiputi there are 4 types.

In the category of endangered bird species, Hot-spot Masihulan has a slightly higher type of other locations as many as 3 types. While other hot-spot locations only have 2 or 1 type only.

\section{Bird diversity index at hot-spot sites}

An index of bird species diversity in hot-spot locations, presented in Table 4. 


\section{Margalef's wealth index}

The Margalef (R1) value of the Margalef (R1) value index indicates that all hot-spot locations have a high to very high level of wealth index due to the resulting wealth index value 7.96515 - 11.21258 (R> 4). This condition is due to the high number of bird species found in all hot-spot locations; ranging from 65 to 98 types, as well as the total number of individuals recorded between $3,174-5,470$ heads.

Separately per location, it is seen that the Hotspot location of Solea and Masihulan has a higher type of wealth index than other hotspot locations, 11.01675 in Masihulan and 11.21258 in Solea. Subsequently followed by Hot-spot Wai Putiputi 10.54128 and Gn.Kaluala 10.18233. While Hot-spot Gn. Kalapahin has the lowest wealth index of 7.96515 .

\section{Shannon-Wiener diversity index}

The value of the Shanon-Winer Diversity Index (H ') indicates that; all hot-spot locations have high Diversity index, because they are above the criteria of $\mathrm{H}$ '> 3 , ie between $3.14544-3.50508$, this shows the level of spread of the individual number of each species is also high.

Separately per hot-spot location shows that Hot-spot Masihulan has the highest diversity index of 3.50508, followed by Hot-spot Solea 3.39336, then Hot-spot Huaulu 3.36120, and lowest is Hot-spot Gn. Kalapahin 3.14544.

\section{The evenness index}

The value of the Equivalency Index (E) indicates; all hot-spot locations have a fairly high evenness index between 0.73339 0.76619 , tend to approach the number 1 . The condition shows the spread of bird species at all hot-spot locations quite evenly and the distribution is quite stable.

Separately per hot-spot location shows that Hot-spot Masihulan has the highest evenness index of 0.76619 , followed by Hot-spot Huaulu 0.75658, Hot-spot Gn. Kalapahin 0.7351 , and so on the location where the lowest evenness index is Wai Hot-spot covers 0.73339 .

\section{Relative abundance of indicator bird types at hot-spot locations}

$\begin{aligned} & \text { Abundance class based on clock } \\ & \text { observation }\end{aligned}$

The class of abundance based on observation hours states how long one species of bird can be observed (when the observer enters its habitat). Table 5 shows;

Abundance Rare with total observed time 3 20 minutes is found in 6 types, namely; Accipiter e., Halcyon l., Myzomela b., Eos s., Eulipoa w., and Lorius d.

Abundance Rare to Uncommon with total observed time between 5 - 50 minutes; there are 7 types namely; Rhipidura $d$., Ninox s., Pachycephala g., Tanysiptera g., Casuarius c.s, Ficedula b., and Micropsitta $b$.

Abundance Uncommon to Often with a total observed time between 22 - 95 minutes, there are in 5 types, namely Ducula c., Alisterus a., Coracina a., Gymnophaps $m$., and Coracina c.

Abundance Uncommon to Common, with total observed time between $33-110$ minutes, there are on 2 types namely; Cacatua $m$., and Charmosyna $p$.

Abundance Often to Common, with total observed time between 70 - 165 minutes, there are on 3 types namely; Rhyticeros p., Myagra g., and Basilornis c.

Abundance Common to Very common, with a 
total observed time between 150 - 322 minutes, there are on 2 types namely; Dicaeum v., and Eos b.

Abundance Very common, with a total observed time between 212 - 441 minutes, is present in 2 types; Ducula $p$. and Philemon s.

When viewed at the total time observed recapitulation per hot-spot location, it appears that; Hot-spot Masihulan has the highest observed total time for all types of indicator birds ie 2,302 minutes. Then, Hot-spot Huaulu 1.968 minutes, Roho Hot-spot 1888 minutes, Hot-spot Gn. Kaluala 1876 minutes, while 3 other hot-spot locations have a total recapitulation time observed all species of birds indicator was recorded lower.

\section{Frequency of availability (Fi)}

The resulting frequency value of the resulting state indicates how widely one species of bird spread at the site under study. Table 6 shows the frequency of availability of the indicator bird species varies greatly from very low ie $2.5 \%$ to very high reaching $100 \%$.

High frequency of availability is found in 5 species of birds, namely; Philemon s., Dicaeum v., Eos b., Ducula p., And Rhyticeros p., 5 species of birds have frequency value> $50,1 \%$ in all hot-spot locations even there are 2 types that have frequency of $100 \%$ in hot-spot Masihulan i.e., Philemon s., and Eos $b$.

Medium frequency of availability with frequency value $>10,1 \%-50 \%$ recorded on 9 species of bird that is; Basilornis c., Myagra g., Cacatua m., Charmosyna p., Alisterus a., Coracina a., Rhipidura d., Pachycephala g., and Coracina c.

Low frequency of availability with frequency value $<10,1 \%$ recorded on 13 species of bird that is; Ducula c., Gymnophaps m., Ficedula b., Ninox s., Tanysiptera g., Accipiter e., Casuarius c., Myzomela b., Eos s., Micropsitta b., Halcyon l., Eulipoa w., and Lorius d.

When looking at the total value of the frequency of encounter per hot-spot location, the highest frequency of bird species indicator is found in 3 locations, namely; Hot-spot Masihulan of 795, Hot-spot Gn. Kaluala 737.5 and Hot-spot Solea 715. Then followed by Roho Hotspot 695 and Huaulu Hotspot 692.5, and the lowest total frequency value of availability is Hot-spot Gn. Kalapahin 572,5 and Wai Hot-spot 552.5.

\section{Ecotourism guidance}

The diversity and relative abundance values of bird species in the above discussion can be a strong argument when explaining the profile and status of interesting and important bird species to tourists visiting the hot-spot locations of biodiversity within PFMU Wae Sapalewa that are attracted to the diversity of bird species. The existence of 27 species of bird indicator that is considered attractive as a tourist attraction object directs the form of ecotourism that is appropriate in the area of PFMU Wae Sapalewa in the form of ecotourism of special interest in the form of bird species observation or better known as Bird Watching.

Based on the experience of the author and the information collected at the study site, the bird species that are often the object of observation in bird watching activities are the bird species of certain status, especially the endemic bird species such as; Cacatua moluccensis. Other types of unique status are also included in the Bird Watcher hunt list such as; Microsiptta bruijni. In addition to these types, the indicator bird species studied in this study could be offered to become a bird-eye object that is no less interesting. 
The results of the analysis of the high wealth index can be used to convince tourists that the level of bird species wealthy in the Wae Sapalewa PFMU area is high. Moreover, the high diversity index of bird species can be used to convince tourists that the diversity of bird species in the PFMU Wae Sapalewa region is high.

The results of the analysis presented in relative abundance based on hours of observation can provide appropriate information to the tourism about the profile and status of bird species. It is such as in endemic bird species, of 9 species of endemic birds found in hot-spot locations recorded there are 4 types observed with a rare class of abundance i.e., Eos semilarvata, Lorius domicella, Halcyon lazuli and Myzomela blasii. 1 type observed with abundance class rare to uncommon, i.e., Rhipidura dedemi. 2 types are observed with uncommon abundance class to common, i.e., Gymnophaps mada and Cacatua moluccensis. 2 types observed with abundance classes are often to very common, ie; Basilornis corythaix and Philemon subcorniculatus. Hotspot locations where such endemic bird species are found are also available to provide certainty for tourists on a sightseeing trip.

Often tourists expect to see relatively abundant species such as endemic Eos semilarvata and Lorius domicella, the information generated in this study provides real-world information on the ground and helps direct tourists to potential locations for encounters with these bird species thus providing certainty of encounter with the type of bird that is expected. The same conditions can be applied to other bird species of different status such as endangered bird species or unique bird species.

Field observation shows $80 \%$ of tourists who do eco-tourism bird watching are foreign tourists, with a prime location in Manusela National Park. While hot-spot locations that have been studied in this research become the location of transit or location of observation between during the national park area. By this research, the hot-spot locations of biodiversity within PFMU Wae Sapalewa area that have been studied can be an attractive ecotourism destination other than Manusela National Park.

Based on observations and information collected, it shows that wildlife species of bird species are more desirable as tourist attraction objects by tourists due to several factors;

Birds are the most attractive and most easily found in the forest area, the attraction of bird life is an object that can provide certainty of satisfaction in an ecotourism trip, when compared with other species of animals that are more difficult to find.

The physical beauty or morphology of birds through beautiful shades and fur colors is a major attraction for travelers with photographi hobbies, and new travelers trying to experience bird watching travel.

The presence status of some species of birds such as endemic species, limited distribution and threatened species globally become its own attraction, which many hunted by tourist. They have the target experience of observation collection of certain bird species in nature. Most tourists who hunt bird species with this particular status is the scientist or teacher at the place of origin.

The sound of wild birds in nature is a very interesting aspect, some bird species especially from a group of callers or passerine groups have a very melodious and very entertaining sound and 
singing. Usually tourists who are obsessed with the sound of birds of a certain type is the scientists, they observe only to add to the collection of sound recordings of birds of interest.

Bird behavior is interesting to observe such as how to eat, roast, cluster, and clean the body, each type has different ways and characteristics that provide variation in the observation. Moreover, some bird species have unique dances that are unique to attract their partner.

The nature of birds that are hard to touch directly, can only be observed, convince that the object of attraction of ecotourism bird watching will exist in nature and can last a long time, unless the forest area in which their habitat is destroyed.

\section{Ecotourism development related to forestry PFMU Wae Sapalewa}

PFMU Governance Plan Model Wae Sapalewa (2013), states that; The development of ecotourism within the PFMU Wae Sapalewa area is possible as it seeks to exploit the potential of forest areas by meeting the criteria of sustainable forest exploitation. Data and information on the spread of wildlife and plants as well as the condition of tourist attraction / ecotourism become a part of concern in the preparation of PFMU Governance Plan Wae Sapalewa. Criteria for the distribution of wildlife and plants is done by endemic type approach, while the criterion of tourist attraction depends on the existence of tourist attraction in the form of waterfalls, caves, landscapes, etc.

The allocation and utilization of management blocks in PFMU Governance Wae Sapalewa provides sufficient opportunity for ecotourism business development within PFMU Wae
Sapalewa area, of course, taking into account the criteria set for the designation and utilization of the management blocks. In addition, the development of ecotourism business will strengthen the allocation and utilization of management blocks outside the block of utilization of wood forest products, especially on special blocks; block of area utilization; and protection blocks.

The results of this study specifically show which locations or on which management blocks have ecotourism potential in the form of hot-spot biodiversity locations that can be utilized by PFMU Wae Sapalewa organization for ecotourism business development.

Development of ecotourism business within PFMU area Model Wae Sapalewa, can be a strategic consideration in the future, because in ecotourism there is no exploitation activity of tree stands, which is used only beauty, uniqueness, and adventure. If possible, ecotourism can be a long-term alternative income for PFMU Wae Sapalewa, and be a profitable business corporation if managed properly and professionally. This emphasizes that the implementation of ecotourism within PFMU Wae Sapalewa must pay attention to the conservation principle, where its management must also use conservation strategy (Dephutbun, 2000).

Ecotourism Bird watching is closely related to the conservation principle, because it is enjoyed only by the attractions and activities of various bird species in nature, without touching or catching. This form of ecological tourism is very precise in maintaining the integrity and authenticity of ecosystem within PFMU Wae Sapalewa region. 
Table.1 Location of terrestrial search and territory conditions

\begin{tabular}{|r|l|l|l|}
\hline No & \multicolumn{1}{|c|}{ Location } & \multicolumn{1}{|c|}{ Physiographic Conditions } & \multicolumn{1}{c|}{ Closure Type Land } \\
\hline $\mathbf{1}$ & Masihulan & Wavy - low hill & Secondary lowland forests \\
\hline $\mathbf{2}$ & Mount Kaluala & Wavy - low- hill & Primary lowland forest \\
\hline $\mathbf{3}$ & Huaulu & Wavy - low- hill & lowland forests of ex-logging \\
\hline $\mathbf{4}$ & Roho & Wavy & lowland forests of ex-logging \\
\hline $\mathbf{5}$ & Mount Kalapahin & Hilly & Primary lowland forest \\
\hline $\mathbf{6}$ & Mount Pasasana & Wavy - low- hill & lowland forests of ex-logging \\
\hline $\mathbf{7}$ & Wai Putiputi & Wavy - low- hill & lowland forests of ex-logging \\
\hline $\mathbf{8}$ & Rumasokat & Wavy - low- hill & lowland forests of ex-logging \\
\hline $\mathbf{9}$ & Melinani & Wavy & lowland forests of ex-logging \\
\hline $\mathbf{1 0}$ & Solea & Wavy - low- hill & lowland forests of ex-logging \\
\hline $\mathbf{1 1}$ & Solea Lama & Ramps - Wavy & lowland forests of ex-logging \\
\hline & & & \\
\hline
\end{tabular}

Table.2 Bird species diversity of territorial search results

\begin{tabular}{|c|c|c|c|c|c|c|c|c|c|c|c|}
\hline Search Locations & 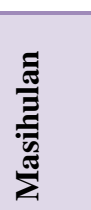 & 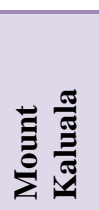 & 를 & $\frac{\varrho}{\varrho}$ & 竞 & 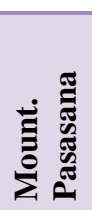 & 离 & 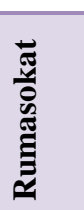 & 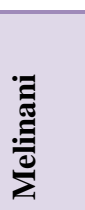 & $\frac{\mathscr{E}}{\frac{0}{0}}$ & 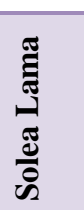 \\
\hline Total Number of Types & 70 & 69 & 54 & 53 & 51 & 43 & 58 & 46 & 54 & 66 & 58 \\
\hline Limited Spread Type & 13 & 14 & 10 & 10 & 11 & 7 & 9 & 6 & 10 & 11 & 11 \\
\hline Type of Endemic & 5 & 6 & 4 & 4 & 4 & 2 & 3 & 2 & 4 & 4 & 5 \\
\hline
\end{tabular}

Table.3 Name of hot spot location and form of PFMU management block Wae Sapalewa

\begin{tabular}{|r|l|l|}
\hline No. & $\begin{array}{l}\text { Hot-spot Location } \\
\text { Names }\end{array}$ & Form of Block Management PFMU Wae Sapalewa \\
\hline $\mathbf{1}$ & Masihulan & HP / Block of Area Utilization \\
\hline $\mathbf{2}$ & Mount Kaluala & HL / Core Block \\
\hline $\mathbf{3}$ & Hualu & HP / Custom Block \\
\hline $\mathbf{4}$ & Roho & HP / Block of Area Utilization \\
\hline $\mathbf{5}$ & Mount Kalapain & HL / Core Block \\
\hline $\mathbf{6}$ & Wai Putiputi & HP / Block of Area Utilization, dan HP / Block Protection \\
\hline $\mathbf{7}$ & Solea & $\begin{array}{l}\text { HP / Block of Area Utilization, dan HP / Block of Utilization non-timber } \\
\text { forest products }\end{array}$ \\
\hline
\end{tabular}

Table.4 An index of diversity of bird species in hot spot locations

\begin{tabular}{|l|r|r|r|r|r|}
\hline \multicolumn{1}{|c|}{$\begin{array}{c}\text { Location } \\
\text { Hot spot }\end{array}$} & $\begin{array}{c}\text { Number } \\
\text { of Species } \\
\text { (S) }\end{array}$ & $\begin{array}{c}\text { Number of } \\
\text { Individual } \\
\text { (N) }\end{array}$ & $\begin{array}{c}\text { Wealth } \\
\text { Index } \\
\text { (R1) }\end{array}$ & $\begin{array}{c}\text { Diversity index } \\
(\mathbf{H})\end{array}$ & $\begin{array}{c}\text { The Evenness } \\
\text { Index (E) }\end{array}$ \\
\hline Masiuhlan & 97 & 5.470 & 11.01675 & -3.50508 & -0.76619 \\
\hline Mt.Kaluala & 87 & 4.588 & 10.18233 & -3.34387 & -0.74875 \\
\hline Huaulu & 85 & 4.721 & 9.88933 & -3.36120 & -0.75658 \\
\hline Roho & 75 & 3.452 & 9.02990 & -3.22109 & -0.74606 \\
\hline Mt. Kalapahin & 65 & 3.174 & 7.96515 & -3.14544 & -0.75351 \\
\hline Wai Putiputi & 90 & 4.233 & 10.54128 & -3.30013 & -0.73339 \\
\hline Solea & 98 & 5.293 & 11.21258 & -3.39336 & -0.74011 \\
\hline
\end{tabular}


Table.5 The relative abundance of bird indicator based on hours of observation

\begin{tabular}{|c|c|c|c|c|c|c|c|c|}
\hline Species & 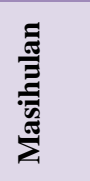 & 芯 & 릌 & $\frac{8}{2}$ & 志 & ๘ & $\frac{\mathscr{J}}{\varnothing}$ & $\begin{array}{c}\text { Class } \\
\text { Abundance }\end{array}$ \\
\hline & \multicolumn{7}{|c|}{ Total Waktu Teramati (Menit) } & \\
\hline Ducula perspicillata $^{B S T}$ & 441 & 345 & 355 & 322 & 283 & 220 & 345 & Very Common \\
\hline Philemon subcorniculatus ${ }^{\text {En.S-BST }}$ & 330 & 222 & 270 & 259 & 207 & 212 & 245 & Very Common \\
\hline Dicaeum vulneratum ${ }^{E n . M-B S T}$ & 322 & 205 & 274 & 286 & 150 & 210 & 227 & $\begin{array}{l}\text { Common - Very } \\
\text { Common }\end{array}$ \\
\hline Eos bornea bornea ${ }^{\text {En.M - BST }}$ & 157 & 187 & 202 & 205 & 151 & 117 & 141 & $\begin{array}{l}\text { Common - Very } \\
\text { Common }\end{array}$ \\
\hline Rhyticeros plicatus $^{U}$ & 125 & 100 & 170 & 125 & 90 & 99 & 125 & Often - Common \\
\hline Myagra galeata $^{B S T}$ & 162 & 125 & 108 & 99 & 90 & 90 & 80 & Often - Common \\
\hline Basilornis corythaix ${ }^{\text {En.S-BST }}$ & 130 & 86 & 125 & 70 & 78 & 80 & 95 & Often - Common \\
\hline Cacatua moluccensis ${ }^{\text {En.S,Kl-BST-VU }}$ & 110 & 101 & 80 & 90 & 85 & 24 & 50 & Uncommon - Common \\
\hline Charmosyna placentis ${ }^{U}$ & 55 & 40 & 90 & 60 & 33 & 110 & 100 & Not common - Common \\
\hline Alisterus amboinensis ${ }^{U}$ & 50 & 86 & 54 & 80 & 28 & 95 & 40 & Uncommon - Often \\
\hline Coracina atriceps ${ }^{\text {En.M - BST }}$ & 85 & 52 & 45 & 35 & 45 & 40 & 25 & Uncommon - Often \\
\hline Gymnophaps mada ${ }^{\text {En.S,B }}$ & 40 & 20 & 30 & 39 & 45 & 30 & 30 & Uncommon - Often \\
\hline Coracina ceramensis ${ }^{\text {En.M - BST }}$ & 55 & 34 & 22 & 25 & 25 & 23 & 24 & Uncommon - Often \\
\hline Ducula concina $^{B S T}$ & 45 & 30 & 54 & 0 & 0 & 0 & 54 & Uncommon - Often \\
\hline Rhipidura dedemi ${ }^{\text {En.S-BST }}$ & 30 & 42 & 10 & 50 & 48 & 24 & 36 & Rare - Uncommon \\
\hline Pachycephala griseonota ${ }^{B S T}$ & 30 & 32 & 17 & 40 & 35 & 18 & 25 & Rare - Uncommon \\
\hline Ninox squamipila $^{B S T}$ & 25 & 25 & 24 & 25 & 5 & 15 & 25 & Rare - Uncommon \\
\hline Tanysiptera galatea $^{U}$ & 22 & 25 & 0 & 30 & 0 & 25 & 40 & Rare - Uncommon \\
\hline Casuarius casuarius $^{U}$ & 10 & 25 & 5 & 24 & 0 & 0 & 35 & Rare - Uncommon \\
\hline Ficedula buruensis ${ }^{\text {En.M - BST }}$ & 25 & 18 & 15 & 6 & 25 & 0 & 0 & Rare - Uncommon \\
\hline Micropsitta bruijnii $^{U}$ & 15 & 30 & 0 & 0 & 15 & 0 & 0 & Rare - Uncommon \\
\hline Accipiter erythrauchen ${ }^{E n . M-B S T}$ & 5 & 7 & 18 & 3 & 20 & 0 & 14 & Rare \\
\hline Halcyon lazuli ${ }^{\text {End.S,A,H -BST - VU }}$ & 18 & 15 & 0 & 10 & 0 & 16 & 0 & Rare \\
\hline Myzomela blasii $^{\text {End.S,B,A - BST }}$ & 3 & 7 & 0 & 0 & 8 & 0 & 0 & Rare \\
\hline Eos semilarvata ${ }^{\text {En.S-BST }}$ & 0 & 15 & 0 & 0 & 17 & 0 & 0 & Rare \\
\hline Eulipoa wallaceii ${ }^{B S T-V U}$ & 0 & 0 & 0 & 0 & 0 & 0 & 12 & Rare \\
\hline Lorius domicella ${ }^{\text {En.S-BST-VU }}$ & 12 & 0 & 0 & 0 & 0 & 0 & 0 & Rare \\
\hline Total Time Recapitulation Observed & 2.302 & 1.876 & 1.968 & 1.883 & 1.483 & 1.448 & 1.768 & \\
\hline$\Sigma$ Common abundance classes & 5 & 3 & 3 & 1 & 3 & 2 & 2 & High Abundance \\
\hline$\Sigma$ Very Common Abundance Class & 3 & 3 & 4 & 4 & 1 & 3 & 3 & \\
\hline$\Sigma$ Often Abundance classes & 3 & 4 & 4 & 5 & 4 & 4 & 4 & Medium Abundance \\
\hline$\Sigma$ Rare abundance Class & 8 & 8 & 12 & 9 & 11 & 13 & 8 & Low Abundance \\
\hline$\Sigma$ Uncommon abundance class & 8 & 9 & 4 & 8 & 8 & 5 & 10 & \\
\hline
\end{tabular}


Table.6 The frequency value of the availability of the indicator bird species at the hot-spot location

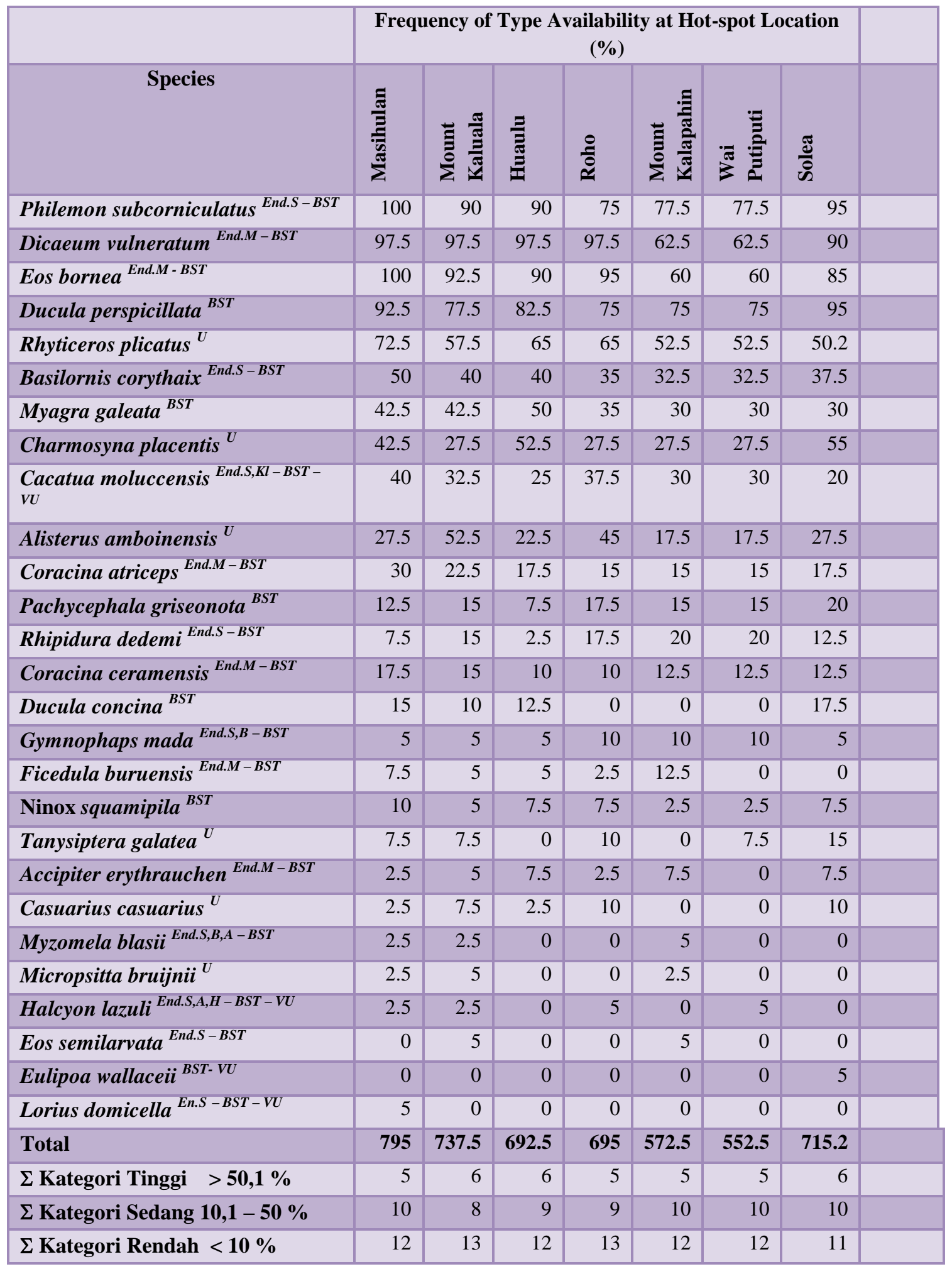


Figure.1 Point count form and placement in transects

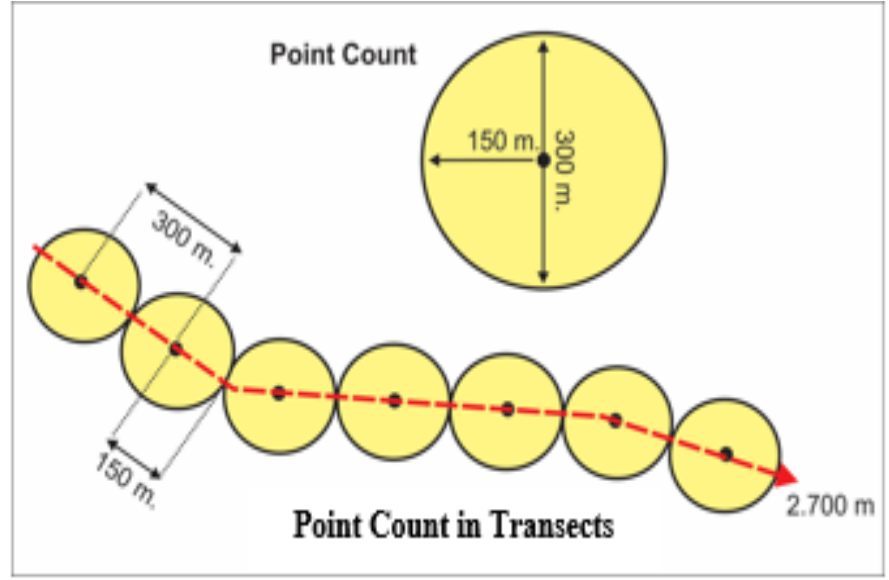

Figure.2 Distribution of the territorial search path Study Area and habitat sample distribution

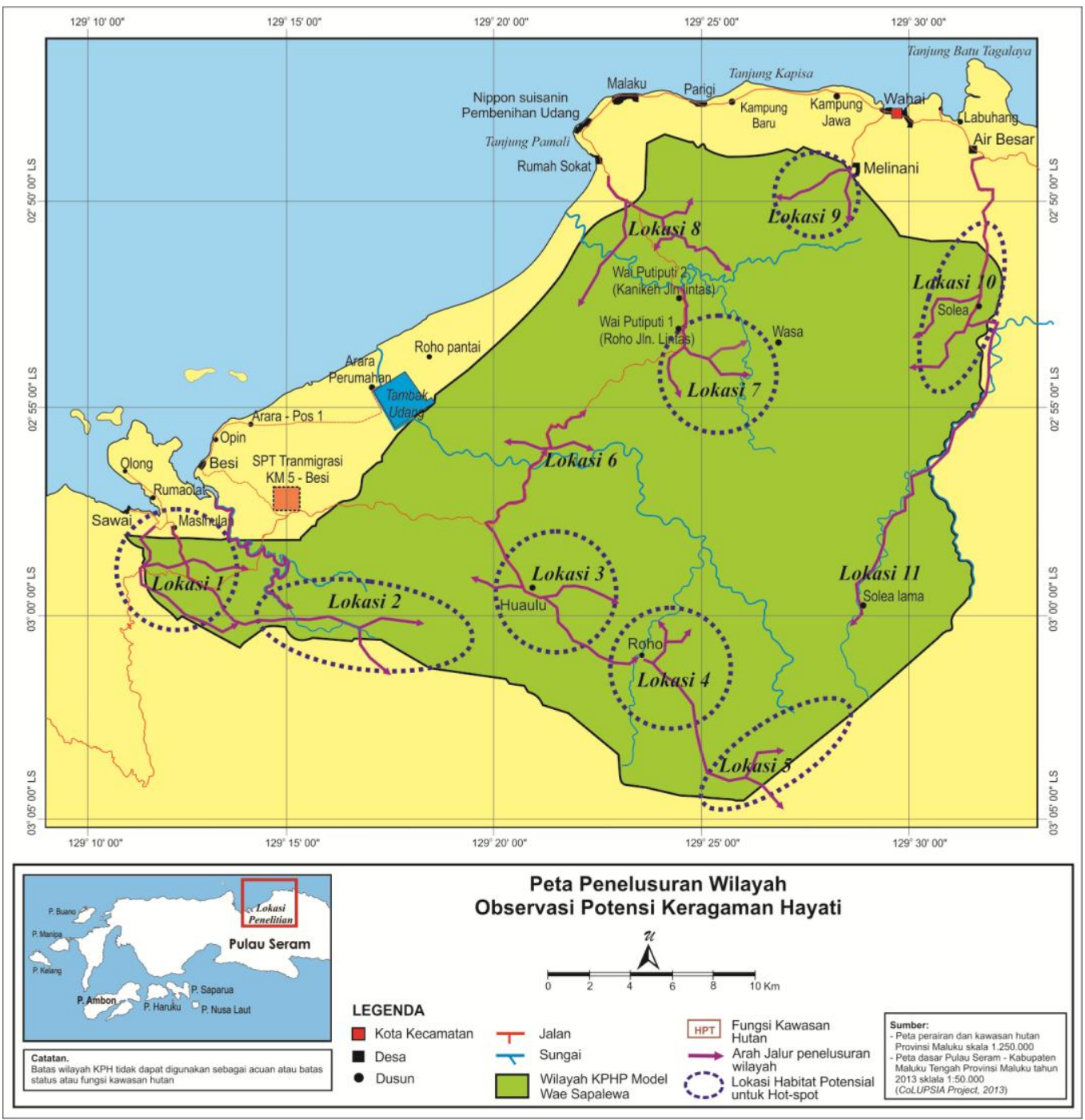


Figure.3 Distribution of hot spot location on PFMU management block map Wae Sapalewa

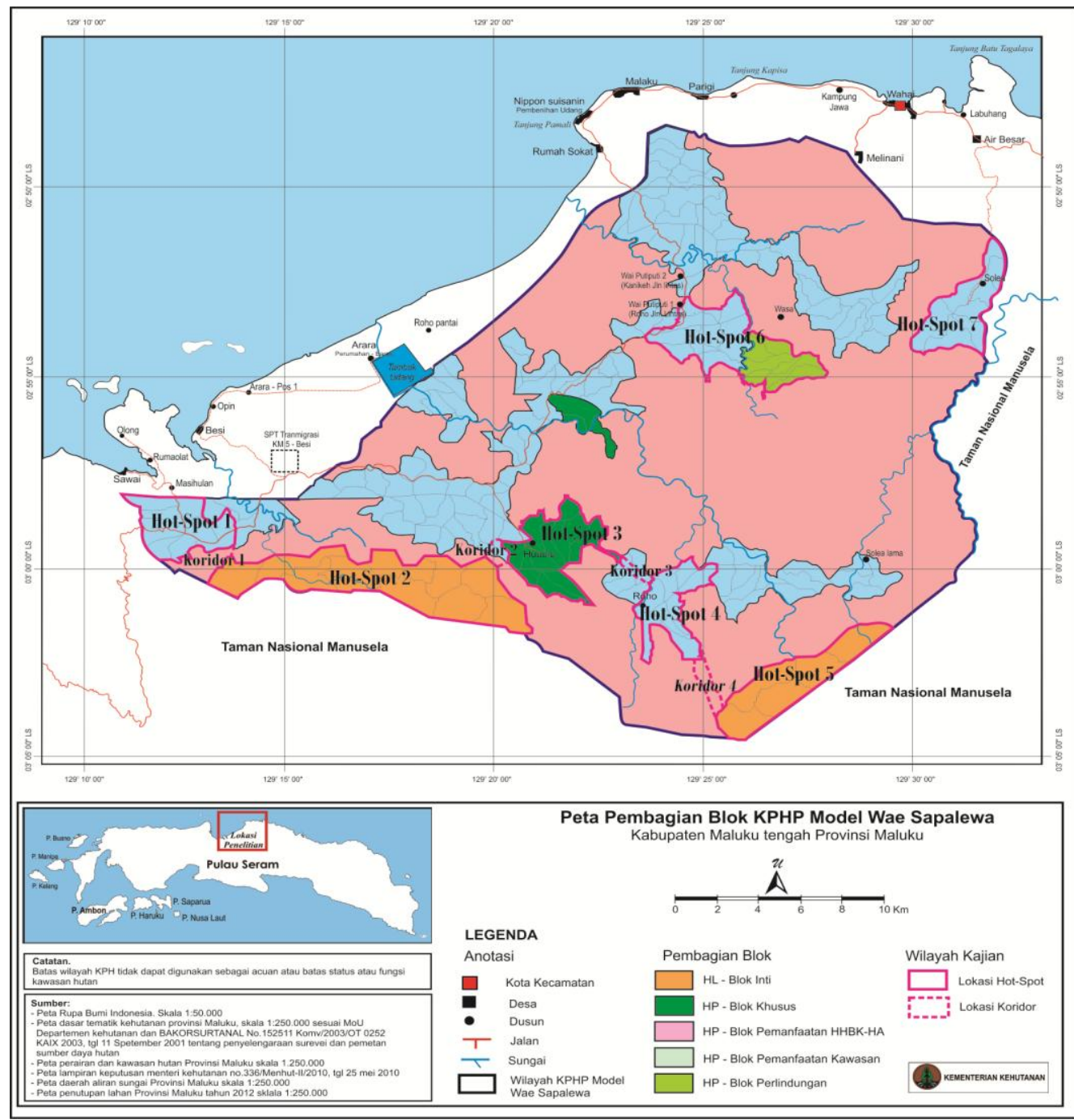

Fugure.4 Graph of bird species encounter in 7 locations of biodiversity hot spots




Figure.5 Encounter of the number of bird species per type category in 7 hot-spot locations

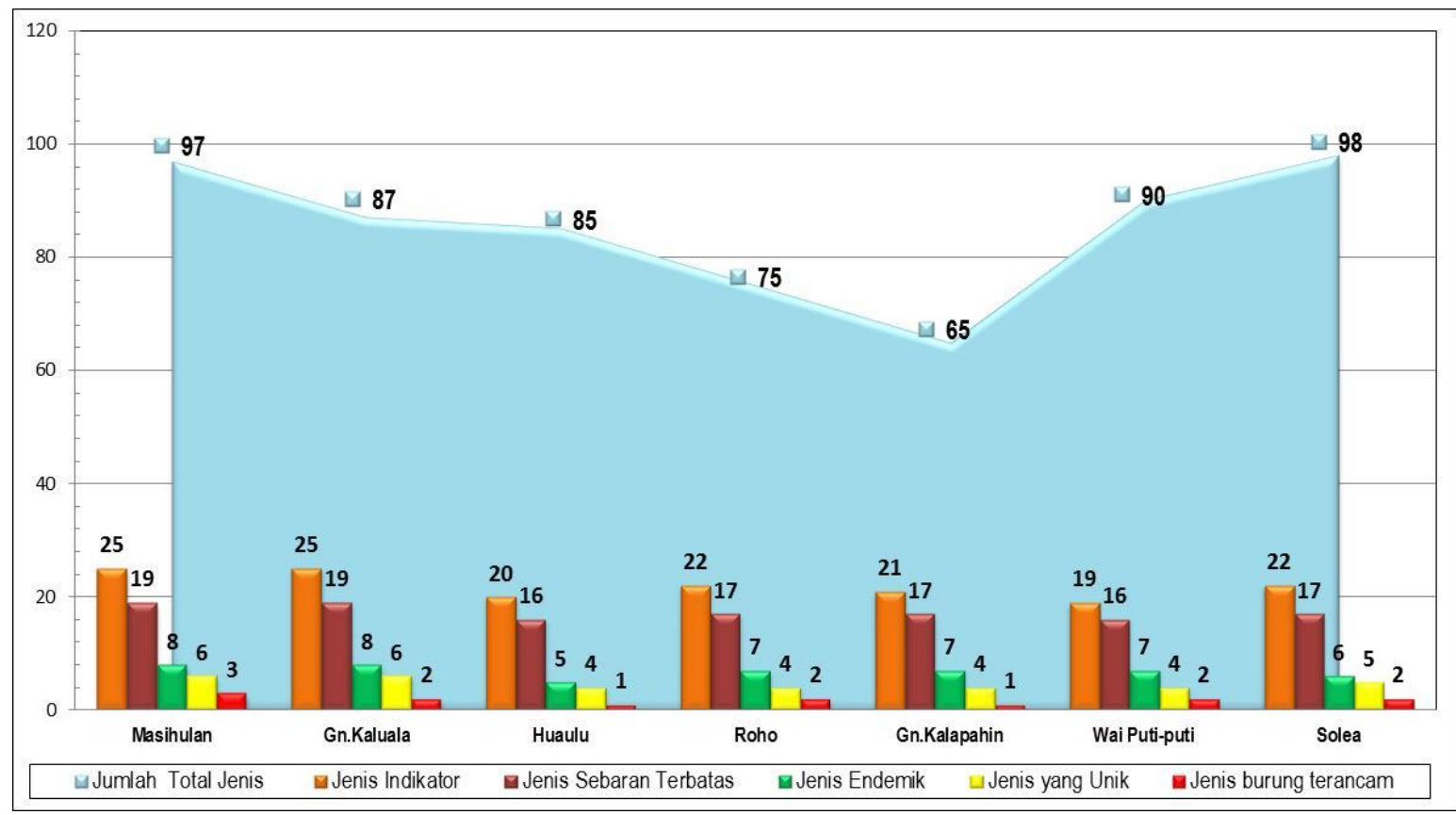

The development of ecotourism forms Bird watching not only shows the uniqueness of biodiversity in biodiversity hotspots locations within PFMU Wae Sapalewa, but also promotes the uniqueness of biodiversity in Seram Island and promotes the uniqueness of biodiversity in Maluku.

The conclusion of the studies is as follows:

PFMU Wai Sapalewa has the potential to become an ecotourism location because it has ecotourism attraction. This research has identified 7 hot-spot locations of biodiversity that can be the location of ecotourism attraction. There are 122 species of birds, 4 species of endangered birds, 9 species of Seram endemic birds, 6 species of birds are unique, and 21 species of limited birds.

The species diversity index of birds in all hotspot locations shows a high value on the wealth index; index of diversity; and evenness index.

The relative abundance value indicates the variation of bird species abundance in hot spot locations. The variation of relative abundance values describes the profile and status of those species in PFMU Wae Sapalewa area.

A suitable ecotourism form applied within the PFMU area of Wae Sapalewa is a special interest ecological tour. Data and information on bird species that are available on biodiversity hot spots support the form of bird watching ecotourism or Bird watching.

Ecotourism development within PFMU Wae Sapalewa area is possible, as the effort becomes an effort to exploit the potential of forest area by fulfilling the criteria of sustainable forest exploitation.

\section{Suggestion}

In addition to the diversity of bird species, the PFMU Wae Sapalewa region also has a wealth of other biodiversity that must be explored and researched as it has potential as a tourist attraction object in the form of ecological tourism or 
special interest tourism.

The criteria of animal dispersal maps and the attraction of tourist / ecotourism locations in PFMU Governance Model Wae Sapalewa is similar to the hot-spot location determination method in this study, therefore the information generated in this paper is believed to be used to strengthen efforts to exploit the potential of forest areas within to achieve sustainable forest management criteria.

\section{References}

Undang-Undang No. 5 Tahun 1990 tentang Konservasi Sumber Daya Alam Hayati dan Ekosistem. Menteri/Sekretaris Negara Republik Indonesia. Lembaran Negara 1990/49 [Law no. 5 of 1990 on the Conservation of Natural Resources and Ecosystems. Minister / Secretary of State of the Republic of Indonesia. State Gazette 1990/49].

Undang Undang No. 41, tentang Kehutanan. Sekretaris Negara Republik Indonesia. Lembaran Negara Tahun 1999 [Law no. 41 , on Forestry. Secretary of State of the Republic of Indonesia. State Gazette Year 1999], Nomor 167.

Agrawal A dan K. Redford, 2006. Poverty, Development and Biodiversity Conservation: Shooting in the Dark. WCS Working Paper Nomor 26. New York: Wildlife Conservation Society available at http://www.wcs.org/science.

Ambon Forest Area Conservation Area, 2013. Tata Hutan PFMU Model Wae Sapalewa. Laporan Akhir [Tata Hutan PFMU Model Wae Sapalewa. Final report]. Ministry of Forestry Republic of Indonesia Directorate General of Forestry Planning.

Anonim, 1990. Undang Undang No.10 Thn 1990, tentang Kepariwisataan. Menteri
Hukum dan Hak Asasi Manusia Republik Indonesia. Lembaran Negara Republik Indonesia No. 11 [Law No.10 / 1990, on Tourism. Minister of Justice and Human Rights of the Republic of Indonesia. State Gazette of the Republic of Indonesia No. 11].

Bratawinata, A.A. 2001. Ekologi Hutan Hujan Tropis Dan Metode Analisis Hutan [Tropical Rainforest Ecology and Forest Analysis Method]. Cooperation Agency of State University of East Indonesia. Makassar

Brian J. Coates, K. David Bishop, 1997. Aguide to the Birds of Wallcea. Dove Publication; P.O. Box 59. Alderly, Queensland 4051. Australia

Department of Forestry and Plantation, 2000. Tekhnik Pengelolaan dan Kebijakan Konservasi Sumber Daya Alam Hayati [Management Technique and Policy of Natural Resources Conservation]. Proceeding Workshop. Dephutbun, Bogor - Jakarta.

Fandeli C, 2000. Pengembangan Ekowisata dengan paradigm baru pengelolaan areal konservasi [Ecotourism development with a new paradigm of conservation area management]. in Fandeli $\mathrm{C}$ dan Mukhlison (editor): Pengusahaan ekowisata [Ecotourism business], edisi 1. Yogyakarta. Faculty of Forestry Universitas Gadjah Mada.

Ian D. Edward., A. A. Macdonald, J. Proctor, 1993.Natural History of Seram, Maluku, Indonesia. Intercept Limited. P.O Box 716. Andover, Hampshire SP10 1 YG. England.

Indrawan, Mochamad; Richard B. Primack dan Jatna Supriatna, 2007. Biologi Konservasi [Conservation Biology]. Revised edition - Jakarta: Yayasan Obor Indonesia.

Lindberg K, 1991. Policies for maximizing nature tourism ecological and economic benefit. World Resources Institut. 
Margalef D. R., 1958. Information Theory in Ecology. Year-book of the Society for General Systems Research, Vol. 3, pp. 36-71.

Ministry of Forestry, 2003. Keputusan Menteri Kehutanan No.230/KptsII/2003. Tentang Pembentukan Pengelolaan Hutan Produksi [Decree of the Minister of Forestry No.230 / KptsII / 2003. About the Formation of Production Forest Management]. Ministry of Forestry, Jakarta

Ministry of Forestry, 2010. Keputusan Menteri Kehutanan No. 336/MenhutII/2010, tanggal 25 Mei 2010, tentang pembentukan PFMU Model Wai Sapalewa [Minister of Forestry Decree no. 336 / Menhut-II / 2010, dated May 25, 2010, regarding the establishment of PFMU Model Wai Sapalewa]. Ministry of Forestry, Jakarta.

Misra R., 1968. Ecology Workbook. Oxford \& IBH Publishing Company.

RidwanW, 2000. Kebijakan pengembangan ekowisata: Kebijakan pengembangan hutan untuk ekowisata [Ecotourism development policy: Forest development policy for ecotourism] in Fendeli dan Mukhlison (editor). Yogyakarta: cultivation of ecotourism, Faculty of Forestry UGM, UKSDA Yogya dan Pustaka Pelajar p.45-55

Soerianegara I, Indrawan I. 2005. Ekologi
Hutan Indonesia. Bogor: Laboratorium Ekologi Hutan [Forest Ecology of Indonesia. Bogor: Forest Ecology Laboratory], Faculty of Forestry IPB.

Sozer R., Nijman V., dan Shannaz J, 2000. Teknik-Teknik Ekspedisi Lapangan, Survei Burung [Field Expedition Techniques, Bird Surveys]. BirdLife Int - IP. Bogor 16003. Indonesia. Original Edition by: Bibby, C., Jones M. and Marsden S. (1998). Expedition Field Techniques. Expedition Advisory Centre; Royal Geographical Society (with the Institute of British Geographical) 1 Kensington Gore, London SW7 2 AR.

Sujatnika, Jepson P, Soehartono T.R., Crosby M.J. dan Mardiatuti A., 1995. Melestarikan Keanekaragaman Hayati Indonesia. Pendekatan Daerah Burung Endemik [Preserving Indonesia's Biodiversity. Approach to Endemic Bird Area]. Jakarta; PHPA/BirdLife Internasional - Indonesia Programme.

Wallace, G.N. 1993. Pengelolaan pengunjung. Pelajaran dari Taman Nasional Galapagos [Visitor management. Lessons from the Galapagos National Park]. Translation of Book: Ecotourism A Guidance for Planner and Manager. The Ecotourism Society, North Bennington. Yayasan Alam Mitra Indonesia.

\section{How to cite this article:}

Yan E. Persulessy, Robert Oszaer and Jusmy D. Putuhena. 2019. Hot-Spot Biodiversity Approach by using Birds as Indicators for Development of Ecotourism. Int.J.Curr.Microbiol.App.Sci. 8(02): 1675-1692. doi: https://doi.org/10.20546/ijcmas.2019.802.197 